\title{
Performance and mineral metabolism of broiler replacing commercial diet by rice polish and supplementation of citric acid
}

\section{KMS Islam ${ }^{1 *}$, MR Debi ${ }^{1}$ and A Liesegang ${ }^{2}$}

${ }^{1}$ Department of Animal Nutrition, Bangladesh Agricultural University, Mymensingh-2202 Bangladesh; ${ }^{2}$ Institute of Animal Nutrition, Vetsuisse Faculty, University of Zurich, Winterthurerstrasse 260, $\mathrm{CH}-057 \mathrm{Zurich}$, Switzerland

\begin{abstract}
During an experimental period of 28 days citric acid (CA) was tested as a growth promoter instead of antibiotics with replacement of commercial diet by rice polish (RP). Newly 240 hatched broiler chicks (Cobb 500) distributed into eight dietary groups ( 3 replicate cages having 10 birds in each), $1=$ Control (commercial diet), 2=Commercial diet $+0.5 \% \mathrm{CA}, 3=5.0 \% \mathrm{RP}, 4=5.0 \% \mathrm{RP}+0.5 \% \mathrm{CA}, 5=10.0 \% \mathrm{RP}$, $6=10.0 \% \mathrm{RP}+0.5 \% \mathrm{CA}, 7=15.0 \% \mathrm{RP}, 8=15.0 \% \mathrm{RP}+0.5 \% \mathrm{CA}$. Diets were supplemented by acid insoluble ash $(1.0 \%$ Celite) as marker. At the end, blood sample was collected from all birds. Total ash, mineral content and density of tibia were determined. Final body weight $(\mathrm{g} / \mathrm{b})$ of chicks were 1655 , $1733,1642,1694,1618,1656,1613$ and $1631 \mathrm{~g}$, respectively $(P>0.05)$. Feed intake $(\mathrm{g} / \mathrm{bird})$ was $2359,2419,2432,2433,2524,2494,2519$ and $2424 \mathrm{~g}$, respectively $(P>0.05)$. FCR varied $(P<0.05)$ among the groups were 1.48,1.44,1.54,1.49,1.62, 1.55, 1.62 and 1.54, where better FCR was in CA groups comparison to non-CA groups. Retention of $\mathrm{Ca}, \mathrm{P}$ and $\mathrm{Mg}$ increased in CA group's comparison to non-CA groups but replacement of $5.0 \%$ commercial diet (with or without CA) caused higher retention level. Higher dressing percentage observed in CA group (65.4, 65.9 for group 2,4) comparison to nonCA groups (63.8, 63.9 for groups 1,3). Bone mineral concentration (total ash, $\mathrm{Ca}, \mathrm{P}$ and $\mathrm{Mg}$ ) slightly increased in CA groups ( $P>0.05)$. In general, replacement of a commercial diet by RP up to $15.00 \%$ would be possible maintaining growth performance of broiler where further supplementation of $0.5 \% \mathrm{CA}$ showed more advantages by increasing mineral density of bone.
\end{abstract}

Keywords: : broiler, rice polish, citric acid, performance, mineral metabolism

Bangladesh Animal Husbandry Association. All rights reserved.

Bang. J. Anim. Sci. 2020. 49 (2):159-165

\section{Introduction}

In Bangladesh total livestock production is 3931.37 lakh and total poultry production is 3379.98 lakh (DLS, 2018). For a long time sub therapeutic level of antibiotics are being used in broilers for improved for the improvement of body weight and feed efficiency (Giriprasad et al., 1990; Miles et al., 2006), but many of those develops resistant strain of pathogen and causes health hazard for human via food from animal origin (Khachatourians, 1998). Considering health hazard many alternatives like organic acids, probiotics, prebiotics, herbs and immune stimulants are suggesting by different legislation to provide safe, healthy food from animal origin. Citric acid is an organic acid increased the performance when using $0.5 \%$ level in mash diet of broiler (Islam et al., 2008). It might be a useful additive instead of antibiotic growth promoters such as avilamycin and flavomycin, considering performance and health status of broilers (Chowdhury et al., 2009a; Haque et al.,
2010). Not only the innate immunity (Chowdhury et al., 2009b; Haque et al., 2010) but also it enhances specific immunity by increasing antibody titre against New Castle Disease vaccine when added in broiler diet (Das et al., 2012). Some study conducted in laboratory scale with mash diet showed excellent results for growth performance of broiler when citric acid was supplemented (Chowdhury et al., 2009b; Haque et al., 2010). Keeping in mind further study conducted by reducing protein and energy level and concluded that the addition of citric acid compensate the performance of broiler depressed due to lowering the nutrients in diet at certain level (Das et al., 2012). A recent study observed that addition of $0.75 \%$ citric acid in a commercial diet suitable for growth, carcass traits, macro mineral digestibility and bone mineral density of broiler chicks (Islam et al., 2012). But in commercial diet all the nutrients were well balanced to optimize the growth, so citric acid might not show its effect with full potentiality as well as increase the feed cost per unit weight 
gain. Considering the points the study designed to replace commercial diet by rice polish considering lower nutrient content and availability but addition of citric acid to know the performance, mineral digestibility and their metabolism.

\section{Materials and Methods}

\section{Birds, feeding and management}

Two hundred and forty unsexed day old Cobb500 broiler chicks were kept in 24 pens of 16 square fit with 10 birds per pen. Commercial broiler starter diet, but with $1.0 \%$ Celite was added as a tracer considered as control diet (Table 1). Birds were divided into 8 dietary groups like $1=$ Control (commercial diet), $2=$ Commercial diet $+0.5 \% \quad C A, 3=5.0 \%$ rice polish (RP), $4=5.0 \% \mathrm{RP}+0.5 \% \mathrm{CA}, 5=10.0 \% \mathrm{RP}$, $6=10.0 \%$ RP $+0.5 \%$ CA, $7=15.0 \%$ RP, $8=15.0 \%$ $\mathrm{RP}+0.5 \% \mathrm{CA}$. Feeding trial was conducted for a period of 28 days.The proximate components of the formulated diets were determined (Table 1) according to the method described by AOAC (1990).

The chicks were handled carefully according to the guidelines of the animal welfare committee of the Faculty of Animal Husbandry, Bangladesh Agricultura University. The birds were kept on deep litter. At the beginning, the room temperature was $34^{\circ} \mathrm{C}$. This temperature was decreased to $22^{\circ} \mathrm{C}$ over the first 3 weeks. Feed was supplied and the amount of leftover feed was recorded when the birds were weighed each week.

\section{Sampling and analysis of feed and excreta}

Feed and excreta sample were collected during the last week of the trial to determine dry matter, total ash, and acid insoluble ash, $\mathrm{Ca}, \mathrm{P}$ and $\mathrm{Mg}$. The amount of $\mathrm{Ca}, \mathrm{P}$, and $\mathrm{Mg}$ were determined by auto analyzer (Cobas Mira, Roche, Basel, Switzerland) using standard commercial kits. The digestibility of individual minerals and metabolizable energy was calculated using the following formula.

Apparent digestibility $(\%)=100-[(\%$ indicator in feed $/ \%$ indicator in excreta $) \times(\%$ nutrient in excreta / \% nutrient in feed) $\times 100$ ]

\section{Determination of blood profiles related to mineral metabolism}

Blood samples were drawn from birds during age of 28 days to determine mineral concentration (Ca, $\mathrm{P}$ and $\mathrm{Mg}$ ). Immediately after collection, blood samples centrifuged at $1500 \mathrm{rpm}$ for 10 minutes and serum transferred to a test tube for further analysis.

\section{Determination of mineral density of tibia}

The tibias from each side of the sacrificed birds were chosen, excised from the fresh carcass, and flesh was removed. The tibia individually sealed in a plastic bag to minimize moisture loss. Forty (10 from each group) tibias from the right side were kept in the refrigerator at $4^{\circ} \mathrm{C}$. Mineral content was measured using the peripheral quantitative computed tomography (QCT) method (Stratec XCT 960A, Pforzheim, Germany), scanning at 10,50 , and 90 percent longitudinal location of the tibia for total, trabecular and cortical bone of mineral density.

Table 1: Composition $(\mathrm{g} / \mathrm{100 \textrm {g }})$ of diet in different experimental groups

\begin{tabular}{lcccccccc}
\hline Groups & 1 & 2 & 3 & 4 & 5 & 6 & 7 & 8 \\
\hline DM $(\mathrm{g} / 100 \mathrm{~g})$ & 88.00 & 87.56 & 88.10 & 87.67 & 88.20 & 87.76 & 88.30 & 87.87 \\
Crude protein & 23.00 & 22.89 & 22.50 & 22.44 & 22.00 & 21.91 & 21.50 & 21.40 \\
Crude fibre & 4.50 & 4.48 & 5.00 & 5.03 & 5.60 & 5.67 & 6.15 & 6.12 \\
Ether Extract & 7.00 & 6.97 & 7.05 & 7.02 & 7.10 & 7.06 & 7.15 & 7.12 \\
Ash & 8.12 & 8.08 & 8.34 & 8.30 & 8.56 & 8.52 & 8.78 & 8.73 \\
Ca & 0.96 & 1.01 & 0.88 & 0.90 & 0.90 & 0.89 & 0.81 & 0.85 \\
P & 0.58 & 0.60 & 0.54 & 0.54 & 0.65 & 0.68 & 0.67 & 0.68 \\
Mg & 0.29 & 0.30 & 0.31 & 0.32 & 0.34 & 0.34 & 0.36 & 0.37 \\
\hline
\end{tabular}

1, Control (commercial diet); 2, Commercial diet $+0.5 \% C A ; 3,5.0 \%$ rice polish $(R P) ; 4,5.0 \% R P+0.5 \% C A$; $5,10.0 \% R P ; 6,10.0 \% R P+0.5 \% C A ; 7,15.0 \% R P ; 8,15.0 \% R P+0.5 \% C A$. 
Determination of dry matter, ash, $\mathrm{Ca}, \mathrm{P}$, and Mg of the tibia

The tibia dried at $105^{\circ} \mathrm{C}$ for $48 \mathrm{~h}$ and placed in a desiccators and weight recorded. Total ash was determined by placing dried tibia in muffle furnace for 24 hours at $600^{\circ} \mathrm{C}$. Percentage of tibia ash calculated according to the procedure of AlBatshan et al. (1994).

\section{Statistical analysis}

Initially, the raw data was organized using the computer program Excel (Microsoft Corporation, Renton, WA) and then analyzed using the SPSS 11.5 (SPSS Inc., Chicago, IL). All data analyzed by 1-way ANOVA, and Duncan's multiple range test (Duncan, 1955) conducted to determine the differences among the treatment means (Steel and Torrie, 1980).

\section{Results}

\section{Growth performance of broiler}

Initial weight per bird was $59.2 \mathrm{~g} \pm 0.6$. Live weight gain does not hampered by the reduction of nutrient content by replacing the commercial diet up to $15.00 \%$ by rice polish (Table 2). Replacement of commercial diet reduces the crude protein and ether extract content of diet but the reduction compensated by the addition of CA reflecting similar weigh in all groups $(P>0.05)$. Crude fiber content increased linearly in rice polish group but its adverse effect not reflected in the growth performance of broiler. It seems that feed intake were numerically highest $(2524 \mathrm{~g})$ in group 5 and lowest $(2359 \mathrm{~g})$ in control group $(P>0.05)$. Feed conversion ratio was higher in the group where commercial diet replaced by rice polish by 10.0 and $15.0 \%(P<0.05)$ in group 5 and 7 respectively but was similar for the groups 6 and 8 where CA was added ( $P>0.05)$.

\section{Mineral content in blood}

Replacement of commercial diet by rice polish caused some variation of $\mathrm{Ca}, \mathrm{P}$ and $\mathrm{Mg}$ concentration in blood serum but, there is a clear indication of increased their concentration in CA groups comparison to non-CA group of similar nutrient containing diet (Table 3 ).

Table 2: Growth performance of birds in different experimental groups

\begin{tabular}{lccccccccc}
\hline Groups & 1 & 2 & 3 & 4 & 5 & 6 & 7 & 8 \\
\hline Initial weight (g/b) & 59.2 & 59.2 & 59.3 & 59.1 & 59.4 & 59.2 & 59.3 & 59.1 \\
& \pm 0.6 & \pm 0.4 & \pm 1.8 & \pm 0.8 & \pm 2.6 & \pm 1.5 & \pm 2.2 & \pm 3.1 \\
\hline Weight gain (g/b) & 1596 & 1674 & 1583 & 1635 & 1558 & 1597 & 1554 & 1571 \\
& \pm 58 & \pm 58 & \pm 69 & \pm 80 & \pm 49 & \pm 73 & \pm 38 & \pm 83 \\
\hline Feed intake(g/b) & 2359 & 2419 & 2432 & 2433 & 2524 & 2494 & 2519 & 2424 \\
& \pm 5 & \pm 136 & \pm 159 & \pm 164 & \pm 166 & \pm 145 & \pm 158 & \pm 163 \\
\hline Feed conversion & $1.48^{\mathrm{a}}$ & $1.44^{\mathrm{a}}$ & $1.54^{\mathrm{abc}}$ & $1.49^{\mathrm{ab}}$ & $1.62^{\mathrm{c}}$ & $1.55^{\mathrm{abc}}$ & $1.62^{\mathrm{c}}$ & $1.54^{\mathrm{abc}}$ \\
ratio & \pm 0.09 & \pm 0.03 & \pm 0.05 & \pm 0.04 & \pm 0.08 & \pm 0.02 & \pm 0.14 & \pm 0.02 \\
\hline
\end{tabular}

${ }^{*}$ Mean \pm standard error $(n=30)$. $a, b, c$, Means with different superscript in the same raw differ significantly $((P<0.05)$. 1, Control (commercial diet); 2, Commercial diet $+0.5 \% C A ; 3,5.0 \%$ rice polish $(R P) ; 4,5.0 \% R P$ $+0.5 \% C A ; 5,10.0 \% R P ; 6,10.0 \% R P+0.5 \% C A ; 7,15.0 \% R P ; 8,15.0 \% R P+0.5 \% C A$.

Table 3: $\mathrm{Ca}, \mathrm{P}$ and $\mathrm{Mg}$ content in blood serum of different experimental groups of birds

\begin{tabular}{lcccccccc}
\hline Groups & 1 & 2 & 3 & 4 & 5 & 6 & 7 & 8 \\
\hline Ca $(\mathrm{mmol} / \mathrm{l})$ & 1.95 & 2.00 & 1.62 & 1.74 & 1.47 & 1.49 & 1.84 & 2.29 \\
& $\pm 0.26^{\text {cd }}$ & $\pm 0.28^{\mathrm{d}}$ & $\pm 0.24^{\mathrm{ab}}$ & $\pm 0.43^{\mathrm{bc}}$ & $\pm 0.19^{\mathrm{a}}$ & $\pm 0.27^{\mathrm{a}}$ & $\pm 0.42^{\mathrm{bcd}}$ & $\pm 0.30^{\mathrm{e}}$ \\
\hline $\mathrm{P}(\mathrm{mmol} / \mathrm{l})$ & 1.97 & 2.00 & 1.69 & 1.76 & 1.57 & 1.59 & 1.59 & 1.81 \\
& $\pm 0.26^{\mathrm{ab}}$ & $\pm 0.26^{\mathrm{a}}$ & $\pm 0.24^{\mathrm{cd}}$ & $\pm 0.31^{\mathrm{cd}}$ & $\pm 0.14^{\mathrm{d}}$ & $\pm 0.14^{\mathrm{d}}$ & $\pm 0.22^{\mathrm{d}}$ & $\pm 0.20^{\mathrm{bc}}$ \\
\hline $\mathrm{Mg}(\mathrm{mmol} / \mathrm{l})$ & 0.74 & 0.79 & 0.61 & 0.64 & 0.58 & 0.61 & 0.64 & 0.75 \\
& $\pm 0.10^{\mathrm{a}}$ & $\pm 0.08^{\mathrm{a}}$ & $\pm 0.08^{\mathrm{b}}$ & $\pm 0.13^{\mathrm{b}}$ & $\pm 0.08^{\mathrm{bc}}$ & $\pm 0.08^{\mathrm{c}}$ & $\pm 0.11^{\mathrm{b}}$ & $\pm 0.08^{\mathrm{a}}$ \\
\hline
\end{tabular}

${ }^{*}$ Mean \pm standard error $(n=30)$. ${ }^{a}, b, c$, Means with different superscript in the same raw differ significantly $((P<0.05)$. 1, Control (commercial diet); 2, Commercial diet $+0.5 \% C A ; 3,5.0 \%$ rice polish $(R P) ; 4,5.0 \% R P$ $+0.5 \% C A ; 5,10.0 \% R P ; 6,10.0 \% R P+0.5 \% C A ; 7,15.0 \% R P ; 8,15.0 \% R P+0.5 \% C A$. 
Islam et al. (2020) Bang. J. Anim. Sci. 49 (2):159-165

Table 4: Mineral density $\left(\mathrm{mg} / \mathrm{cm}^{3}\right)$ of bone due to dietary citric acid in different groups

\begin{tabular}{lcccc}
\hline Groups & 1 & 2 & 3 & 4 \\
\hline Total density $(10 \%)$ & $218 \pm 18^{\mathrm{a}}$ & $208 \pm 26^{\mathrm{a}}$ & $200 \pm 23^{\mathrm{a}}$ & $223 \pm 26^{\mathrm{a}}$ \\
Trab. density $(10 \%)$ & $135 \pm 40^{\mathrm{a}}$ & $111 \pm 40^{\mathrm{a}}$ & $106 \pm 50^{\mathrm{a}}$ & $121 \pm 47^{\mathrm{a}}$ \\
Cort. density $(10 \%)$ & $295 \pm 9^{\mathrm{a}}$ & $305 \pm 42^{\mathrm{a}}$ & $297 \pm 15^{\mathrm{a}}$ & $313 \pm 35^{\mathrm{a}}$ \\
\hline Total density $(50 \%)$ & $435 \pm 46^{\mathrm{ab}}$ & $398 \pm 83^{\mathrm{bc}}$ & $374 \pm 28^{\mathrm{c}}$ & $456 \pm 32^{\mathrm{a}}$ \\
Cort. density $(50 \%)$ & $618 \pm 38^{\mathrm{a}}$ & $568 \pm 102^{\mathrm{b}}$ & $558 \pm 11^{\mathrm{b}}$ & $632 \pm 23^{\mathrm{a}}$ \\
\hline Total density $(90 \%)$ & $229 \pm 15^{\mathrm{ab}}$ & $241 \pm 13^{\mathrm{a}}$ & $204 \pm 17^{\mathrm{c}}$ & $224 \pm 17^{\mathrm{bc}}$ \\
Trab. density $(90 \%)$ & $153 \pm 43^{\mathrm{ab}}$ & $177 \pm 28^{\mathrm{a}}$ & $137 \pm 33^{\mathrm{b}}$ & $134 \pm 44^{\mathrm{b}}$ \\
Cort. density $(90 \%)$ & $316 \pm 30^{\mathrm{a}}$ & $320 \pm 28^{\mathrm{a}}$ & $290 \pm 10^{\mathrm{b}}$ & $326 \pm 31^{\mathrm{a}}$ \\
\hline
\end{tabular}

${ }^{*}$ Mean \pm standard error $(n=30)$. ${ }^{a}, b, c$, Means with different superscript in the same raw differ significantly $((P<0.05)$. 1, Control (commercial diet); 2, Commercial diet $+0.5 \% C A ; 3,5.0 \%$ rice polish $(R P) ; 4,5.0 \% R P$ $+0.5 \% C A ; 5,10.0 \% R P ; 6,10.0 \% R P+0.5 \% C A ; 7,15.0 \% R P ; 8,15.0 \% R P+0.5 \% C A$.

\section{Digestibility of $\mathrm{Ca}, \mathrm{P}$ and $\mathrm{Mg}$}

Digestibility of $\mathrm{Ca}, \mathrm{P}$ and $\mathrm{Mg}$ found higher in $\mathrm{CA}$ groups in comparison to non-CA groups. Although, in different groups showed variation as the nutrient content slightly varied among the groups (Table 1 and Figures $1 \mathrm{a}, 1 \mathrm{~b}$ and 1c)). Digestibility of $\mathrm{Ca}, \mathrm{P}$ and $\mathrm{Mg}$ increased in $\mathrm{CA}$ groups comparison to non-CA groups, but was highest in $5.0 \%$ rice polish, which is also true for energy digestibility (Figure $1 \mathrm{a}, 1 \mathrm{~b}, 1 \mathrm{c}$ and 2 ).

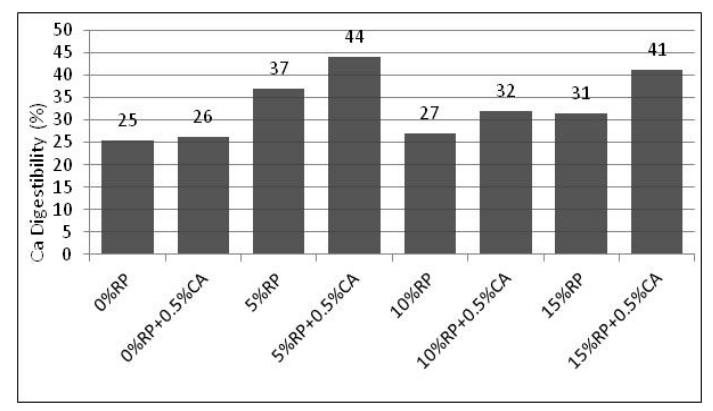

Figure 1a. Digestibility of $\mathrm{Ca}$ in different dietary groups

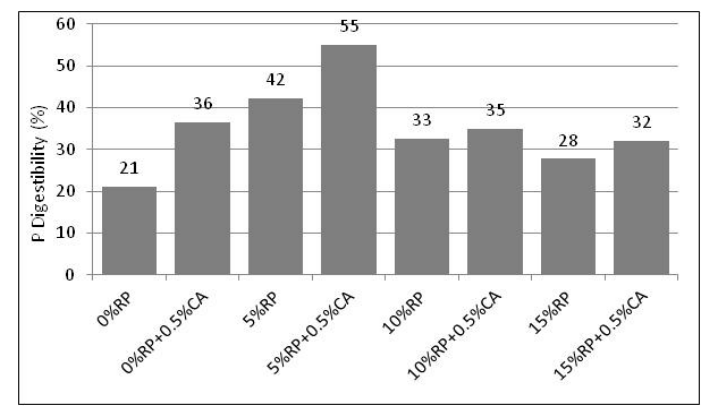

Figure 1b. Digestibility of $P$ in different dietary groups

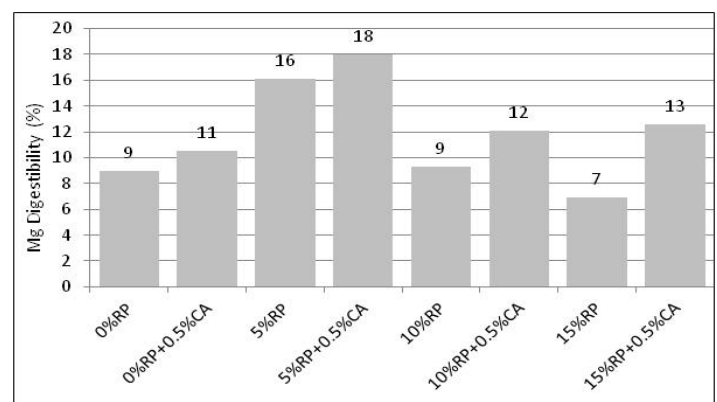

Figure 1c. Digestibility of $\mathrm{Mg}$ in different dietary groups

\section{Ash content and mineral density in bone}

Ash content in control group and further addition of $0.5 \%$ CA showed no significant differences but when replaced commercial diet by $5.0 \%$ level of rice polish showed slightly increased level of mineral content as well as mineral density in tibia (Figure 3 and Table 4).

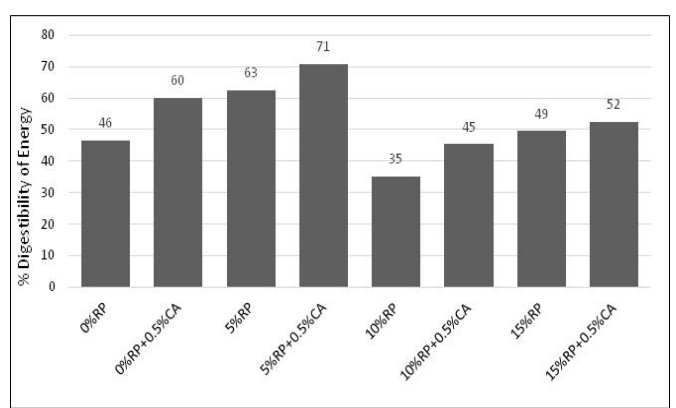

Figure 2: Digestible energy in different dietary groups 


\section{Rice polish in broiler diet}

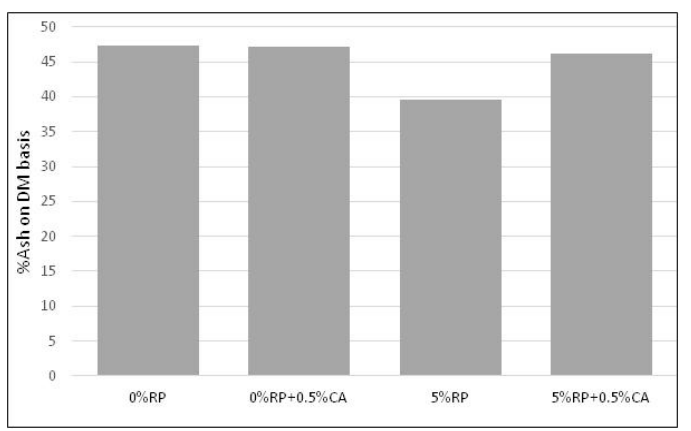

Figure 3: Mineral content of bone ( $g / 100 \mathrm{gm} D M)$ in different dietary groups

\section{Discussion}

\section{Growth performance of broiler}

Haque et al., (2010) found that dietary supplementation of $0.5 \%$ CA increase weight gain, feed intake, feed conversion efficiency, tibia ash deposition, non-specific immunity and carcass yield of broiler. Chowdhury et al., (2009b) found similar results when CA used as a feed additive instead of the antibiotic growth promoter Avilamycin. The results of this study are in an agreement with also the previous reports (Nezhad et al., 2007; Moghadam et al., 2006). Shahin et al., (2009) found that addition of CA in commercial diet at $0.8 \%$ level increased $4.9 \%$ weight in broiler which is also true in this trial that addition of CA increased live weight gain in comparison to non-CA groups. Most of the cases the lower limit of CA support the growth performance of broiler positively. So, compensation of growth due to reduction of nutrients by addition of rice polish was possible due to presence of CA at lower limit.

In this study feed intake was similar in all the groups either replacing by rice polish and addition of CA ( $P>0.05)$, which is in agreement with other findings (Shahin et al., 2009; Islam et al., 2010a). But some findings showed that feed intake increased than observed in this trial due to feeding rice bran, but they added $2.0 \% \mathrm{CA}$ in broiler diet (Atapattu and Nelligaswatta, 2005).

Many researchers reported that addition of CA in broiler diet has positive effect on feed efficiency (Huifang et al., 2005; Nezhad et al., 2007), which also true for this trial. But some other research found numerically improvement of feed efficiency when added in commercial diet (Shahin et al., 2009; Islam et al., 2010a). Huifang et al., (2005) demonstrated the highest feed conversion ratio with addition of $0.3 \% \mathrm{CA}$ in growing chicks. So, it is clear that lower doses have positive effect on the feed efficiency as found in this study although level of nutrient decreased due to replacing the diet by rice polish.

In this study CA containing group have higher carcass grade and it is also similar to the findings of Islam et al., (2012). This result is also in agreement with other investigations (Ebrahimnezhad et al., 2008). Compensation of growth performance in rice polish group observed due to the positive effect of $\mathrm{CA}$, because its addition in animal diet may suppress pathogenic growth and improve digestion of nutrients, absorption of digested nutrients through gastro intestinal tract, improvement of mucosal immunity and topical effects on the intestinal brush border (Mroz, 2005). Reducing the bacterial burden due to addition of $C A$ in feed improved gut health parameters significantly, this may be related to the increased availability of the nutrients.

\section{Mineral content in blood}

When $15.0 \%$ rice polish added in diet replacing commercial diet but included $0.5 \% \mathrm{CA}, \mathrm{Ca}$ content in blood serum rose highest, nearly similar result was found in case of $\mathrm{P}$ and $\mathrm{Mg}$ content. From the report of Islam et al.,(2012) it observed that addition of CA influenced the availability of macro minerals, but this was not detected in the blood profile, which might be due to rapid turnover of those components, as other researcher found no changes of $\mathrm{Ca}, \mathrm{P}$ and $\mathrm{Mg}$ in blood when added $3.0 \% \quad \mathrm{CA}$ in diet (Nourmohammadi et al., 2010).But, other researcher found that $2.0 \% \mathrm{CA}$ in broiler diet increased $\mathrm{Mg}$ level in the blood (Brenes et al., 2003).

\section{Digestibility of $\mathrm{Ca}, \mathrm{P}$ and $\mathrm{Mg}$}

Islam et al., (2010b) reported that the addition of $\mathrm{CA}$ in the diet influenced the availability of minerals. But in this study used commercial diets contained standard level of minerals and replaced by rice polish but added CA at lower level, which is also supported by other researcher showing the $\mathrm{Ca}$ and $\mathrm{P}$ retention was 3.0 and $3.0 \%$ in $2.0 \% \mathrm{CA}$ diet of broiler(Brenes et al.,2003).

\section{Ash content and mineral density in bone}

There are several findings that addition of CA in diet increased bone mineral content and bone strength in different levels (Atapattu and Nelligaswatta 2005; Chowdhury et al., 2009b; Haque et al., 2010; Islam et al., 2010b; Islam et al., 2012;). The increased mineral level in the bone is also related to the availability of the minerals which is responsible for bone formation (Islam, 2012; Boling et al., 2001). In this study both bioavailability and its expression in blood as 
well as in bone is clear that the metabolism of minerals related to bone formation is increased due to presence of CA in diet. So, replacement of commercial diet by rice polish would be possible maintaining the performance and increased mineral density in bone due to addition of CA in commercial diet which is replaced at $15.0 \%$ level by rice polish.

\section{Conclusion}

From above findings it is clear that replacement of commercial diet containing $23.0 \%$ crude protein by $15.0 \%$ rice polish would be possible without hampering performance of broiler. But up to $5.0 \%$ level of rice bran increased digestibility, blood profile and mineral density of bone. For every case, $0.5 \%$ citric acid in diet enhance metabolism of $\mathrm{Ca}, \mathrm{P}$ and $\mathrm{Mg}$ reflected by digestibility, blood profile and bone content of those component. In general, replacement of commercial diet by rice polish up to $15.0 \%$ would be possible maintaining growth performance of broiler where further supplementation of $0.5 \%$ citric acid caused more advantages for performance and mineral metabolism $(P>0.05)$.

\section{Acknowledgment}

Author deeply acknowledges the financial support provided by the Swiss National Science Foundation, Switzerland as visiting fellow to the first author and Ministry of Science and Technology, Peoples Republic of Bangladesh, for financial support to conduct the research.

\section{Conflict of interest}

There is no conflict of interest among the authors.

\section{References}

Al-Batshan HA, SE Scheideler, BL Black, JD Garlich and KE Anderson (1994).Duodenal calcium uptake, femur ash, and increase following molt. Poultry Science 73(10):1590-1596.

Atapattu NSBM and CJ Nelligaswatta (2005).Effects of citric acid on the performance and utilization of phosphorous and crude protein in broiler chickens fed rice byproducts-based diets. International Journal Poultry Science 4(12): 990-993.

AOAC (1990).Official methods of Analysis.15 ${ }^{\text {th }}$ Ed. Association of Official Analytical Chemists, Inc., Arlington, Virginia, USA. .

Boling SD, JL Snow, CM Parsons and DH Baker (2001).The effect of citric acid on the calcium and phosphorus requirements of chicks fed corn-soybean meal diets. Poultry Science 80(6): 783-788.
Brenes A, A Viveros, I Arija, C Centeno, M Pizarro and $C$ Bravo (2003). The effect of citric acid and microbial phytase on mineral utilization in broiler chicks. Animal Feed Science and Technology 110: 201-219.

Chowdhury R, MN Haque, KMS Islam and $A B M$ Khaleduzzaman (2009a). A review on antibiotics in an animal feed. Bangladesh Journal of Animal Science 38(1-2): 22-32.

Chowdhury R, KMS Islam, MJ Khan, MR Karim, MN Haque, M Khatun and GM Pesti (2009b). Effect of citric acid, avilamycin and their combination on the performance, tibia ash and immune status of broiler chicks. Poultry Science 88(8): 1616-1622.

Duncan DB (1955). Multiple range tests and multiple $\mathrm{F}$ test. Biometrics 11:1-42.

Das SK, KMS Islam and MA Islam (2012). Efficacy of citric acid in diet contains low levels of protein and energy on the performance and immunity of broiler. Indian Journal of Animal Sciences 82(6): 629-633.

DLS (Department of Livestock Services) (2018). Livestock economy at a glance, Ministry of Livestock and Fisheries, Dhaka, Bangladesh.

Ebrahimnezhad Y, M Shivazad, R Taherkhani and K Nazeradl (2008).Effects of citric acid and microbial phytase supplementation on performance and phytate phosphorus utilizition in broiler chicks. Journal of Poultry Science 45(1): 20-24.

Giriprasad B, RV Rabindra, SM Siddiqui and PV Rao (1990). A study on the influence of different growth promoters in cockerels. Indian Journal of Poultry Science 52: 381 148-153.

Haque MN, KMS Islam, MA Akbar, MR Karim, R Chowdhury, $M$ Khatun and BW Kemppainen (2010).Effect of dietary citric acid, flavomycin and their combination on the performance, tibia ash and immune status of broiler. Canadian Journal Animal Science 90: 57-63.

Huifang S, H Chuiwang and DUB Wang (2005).Effect of citric acid on production performance of Three Yellow chicken.China Poultry Journal 27: 14-15.

Islam KMS (2012). Use of citric acid in broiler diets. World's Poultry Science Journal 68(1):104-118.

Islam MZ, ZH Khandaker, SD Chowdhury and KMS Islam (2008).Effect of citric acid and acetic acid on the performance of broilers. Journal of Bangladesh Agricultural University 6(2): 315320.

Islam KMS, MN Haque, R Chowdhury, MSA Shahin and KN Islam (2010a). Effect of citric acid administration through water on the performance of broiler fed commercial diet. Bangladesh Journal Progressive Science and Technology 8: 181-184.

Islam KMS, H Schaeublin, C Wenk, M Wanner and A Liesegang (2010b).Effect of dietary citric acid on the performance and mineral metabolism of broiler. ESVCN Proceeding spp. 109. 
Islam KMS, H Schaeublin, C Wenk, M Wanner and A Liesegang (2012). Effect of dietary citric acid on the performance and mineral metabolism of broiler. Journal of Animal Physiology and Animal Nutrition 96(5): 808-817.

Khachatourians GG (1998). Agricultural use of antibiotics and the evolution and transfer of antibiotic-resistant bacteria. Canadian Medical Association Journal 159(9):1129-1136.

Miles RD, GD Butcher, PR Henry and RC Littell (2006).Effect of antibiotic growth promoters on broiler performance intestinal growth parameters, and quantitative morphology. Poultry Science 85(3):476-485.

Moghadam AN, J Pourreza and AH Samie (2006). Effect of different levels of citric acid on calcium and phosphorus efficiencies in broiler chicks. Pakistan Journal of Biological Science 9(7):1250-1256.

Mroz Z (2005).Organic acids as potential alternatives to antibiotic growth promoters for pigs. Advances in Pork Production 16:169.

Nezhad YE, M Shivazad, M Nazeeradl and MMS Babak (2007). Influence of citric acid and microbial phytase on performance and phytate utilization in broiler chicks fed a cornsoybean meal diet. Journal of Veterinary Medicine, University of Tehran 61: 407-413.

Nourmohammadi R, SM Hosseini and H Farhangfar (2010).Effect of dietary acidification on some blood parameters and weekly performance of broiler chickens.Journal of Animal and Veterinary Advances 9(24): 3092-3097.

Shahin MSA, KMS Islam, MA Akbar, MN Haque, R Chowdhury and KN Islam (2009). Effect of citric acid supplementation on the performance of broiler. Indian Journal of Animal Nutrition 16(2): 181-185.

Steel GD and JH Torrie (1980). Principles and Procedure of Statistics. McGrow Hill Book Company, New York. 